\title{
IOWA BANK LAW A BULWARK OF SAFETY
}

\author{
By EMORY H. ENGLISH
}

The long period of liquidation of a considerable group of Iowa banks, which encountered difficulties following the land boom that came with the close of World War $\mathrm{I}$, is now over. The drastic drop in land values and commodity prices had made impossible of payment at maturity the notes of many farmers and others held by the banks. And in turn the banks experienced critical and unprecedented difficulties in payment of withdrawals of deposits whether such withdrawals were due to loss of confidence by depositors or because of unavoidable need of funds.

Personal fortunes and the assets of institutions were greatly impaired, if not wiped out in numerous instances. And generally the trials suffered were severe and crucial in the extreme. Human ingenuity was put to test to save both individuals and institutions from complete insolvency. To the credit of Iowa people, including businessmen, farmers, and bankers, with the leadership of the Iowa Bankers Association and the help of the Iowa legislature, a way out of economic and financial difficulties was finally found and has proved so successful that it merits recording as an important chapter in the history of the state.

The new banking law enacted in January 1933, and characterized as the "bank stabilization bill," in its operation, has not only vindicated the confidence of its progenitors, but stands today as a bulwark of safety against any possible repetition of the dire happenings of those calamitous years. This act contemplated a dual procedure of nursing bank paper in distress until readjustment of the debtor's affairs enabled the realizing of cash from pledged securities, and in the meantime continuing of bank activities under state supervision, without resort to receivership, such action being made possible upon agreement of depositors with stockholders. 
In Iowa prior to 1923 , banks that went into receivership were liquidated by receivers appointed by the courts. The accelerated series of bank closings subsequent to the 1920 economic difficulties in the Hawkeye state led to enactment in 1923 by the legislature the law creating a receivership division in the state banking department. Under this act the state superintendent of banking became receiver for all such state chartered banks requiring liquidation. Primarily this was for the purpose of securing still greater economy and uniformity in practices as well as invoking state authority in dealing with all concerned.

The harm suffered by a community through these receiverships in connection with bank closings was only moderated by the state taking charge. The loss to depositors and stockholders alike was great, and for years banks receivership pursued its relentless course until it touched by far the majority of banking communities of the state and seemingly was unstoppable. Businessmen and the people at large came to know the costliness of a bank receivership.

The course of events showed all too clearly that the bank receivership law of Iowa was too drastic and too inelastic to meet the current economic situation. It gave no discretionary authority to the state superintendent of banking, and yet seemed to be the only law to which he could turn when asked for assistance by any bank that might get into distress owing to the almost impossibility of collecting its notes from borrowers and paying the withdrawal of its deposits.

\section{EARLY EFFORTS TO AID BANKS}

Through patriotic services of the Iowa Bankers Association aid was developed first through voluntary "depositor's agreements" sponsored by committees, their use offering perhaps the only alternative against bank runs or bank receiverships. Influential citizens including farmers and businessmen, not bankers, became active in securing co-operation of depositors in saving 
many institutions. In some communities resort was had to the mayor declaring a "business holiday," but this had devasting results, as during such periods nearly always business was at a standstill.

Eventually it came to be understood that the economic and financial equilibrium of a community and state could only be restored and maintained through establishment and guarantee of stable banking and credit facilities, then all but completely broken down. Constructive work along this line was being accomplished through the labors of the Banking and Agricultural Credit Facilities committee of the Iowa Bankers Association, from the files of which the writer is indebted for recorded details. The laudible work of the members of this committee and officers and members of the association, in the interest of bank reorganization and bank rehabilitation, really gave conception to the principle laid down in the remedial legislation later secured.

From the first there was in the mind of all to evolve some sort of legal substitute for bank receivership. Nothing else would suffice; the emergency undoubtedly would continue until some unique method might be discovered and utilized through means of which the community plague might be dispelled and the harassed financial institution saved from distruction. Need was plain that the bank should have time in which to make collection of its bills receivable, and likewise adequate time to pay out in some orderly way in regular course of business funds thus collected, and continue its accustomed routine service as a local banking institution.

Suggestion of methods of procedure came from many sources. That new legislation would be necessary was quickly agreed. And it would constitute pioneer legislation, for search disclosed no chart or guide in state or national law. A "bank stabilization" bill with two objects was determined upon; the first to make banks "run proof," and the second to avoid receiverships. The occasion and its purposes were ably met. 
The bill framed at a meeting of the committee and officers on January 18, 1933, represented courage and vision of the first order by its initiators, leaders in the movement being Fred J. Figge of Ossian, president, and Frank Warner, of Des Moines, secretary of the Iowa Bankers Association, to whom much credit is due. The final draft, known as Senate File No. 111, was considered by a committee of co-operative legislators and Lieutenant Governor N. G. Krashel took a most active part, with friendly interest in the measure proposed. This was on January 20,1933, and that afternoon the bill was reported out with recommendations for passage by both the senate and house banking committees and senate and house "Emergency" committees. Further conference was held that evening by members of the association and those of the house and senate banking committees, extending until after midnight. During that day plans had also been completed with leaders of the house and senate for the handling of the bill on the floor of each body the next day. On the morning of Friday, January 20, 1933, the house and senate banking committees held a joint executive session. Some additional amendments were put into the bill which were perfectly agreeable to the officers and legislative committee of the Iowa Bankers Association.

\section{BANKS ClOSED IN LARge Numbers}

It then was arranged that the bill should be taken up first in the senate, which should go into executive session in considering the bill. Speed was the watchword, for the reason shown that more than thirty Iowa banking institutions had closed their doors the day previous, and nearly one dozen more had suspended that very day, Friday, January 20, 1933, with others sure to follow, by far the majority of these having invoked banking holidays.

The senate adopted one or more slight and helpful amendments and rewrote a portion of one section which really improved that part of the bill. After discussion 
as to the purposes and reasons for the legislation sought the executive session of the senate was concluded, whereupon in open session the senate proceeded to vote passing the bill about $11: 45 \mathrm{a}$. $\mathrm{m}$. by a vote of 47 to 0 , there being three absent or not voting.

The bill was messaged to the house and at the earliest opportunity the house went into executive session during which the purposes and reasons for the passage of the proposed legislation were discussed, and later the house passed the measure by a vote of 107 to 0 , only one member being absent or not voting.

The act was published in the Ottumwa Daily Courier and in the Des Moines Register on Saturday, January 21, 1933. The publications were certified back to the secretary of state on Saturday, January 21, 1933, a special messenger taking the copy to Ottumwa and waiting there for the printing of the paper containing the act and bringing the certified copy back to the secretary of state's office. Thus the bill became operative on and after Monday, January 23, 1933.

Because of the extraordinary nature of the act extending the powers of the superintendent of banking to take possession of banking institutions and to protect the debtors and creditors of such, and to reorganize or operate the same through agreements between individual depositors and the stockholders, the statute became the best known and generally understood law enacted by the Forty-fiith General Assembly of Iowa.

The original provisions of Senate File 111 as they now stand in the code of 1946 are Sections 528.90 to 528.94 inclusive, one section relating to power of the superintendent of banking to "sell, hypothecate or pledge or exchange any or all assets of banking institutions," being dropped in codifying. The law was much amplified by later enactments in the same session known as House File 541 and Senate File 483, the entire law now applicable appearing as Sections 528.90 through 528.119 as follows : 


\section{The “Bank Stabilization" LaW}

528.90-Management by superintendent-legal and equitable remedies suspended. The superintendent of banking shall, upon application of the officers or directors of any state bank, savings bank or trust company or private bank doing a banking business, have the power, with the consent of the executive council or of the governor or of the lieutenant governor, to take over the management of any such bank and may, at his discretion, manage the same either by its officers or a part thereof or by any suitable person or persons he may select for such purpose. Such period of management by the superintendent of banking shall not, however, extend beyond two years from the date of taking possession unless further extended by authority of the executive council. During the period of such management and possession lby the superintendent of banking, all the remedies at law or in equity of any creditor or stockholder against any such bank or trust company shall be suspended, and the statute of limitations against such claims shall be tolled during such period.

528.91-Powers of superintendent. The superintendent of banking, whenever he shall have taken over the management of any such banking institution as provided in section 528.90 shall have the right and power, with the approval of the executive council, to proceed to wind up its affairs as provided by law; or may continue the operation of the same, holding all deposits in the same, taking in deposits and carrying on the same under such rules and regulations as he may make for the conduct of its business and deem for the best interest of the debtors and creditors of such institution, including the right to compromise any rights, claims, and liabilities of such institution. If such institution is kept open for business under the management of the banking department, and new deposits are received, such deposits shall be segregated, and any new assets acquired on account of such deposits shall be segregated and held in trust especially for such new deposits.

528.92-Power to reorganize. However, if in the opinion of the superintendent of banking it is deemed advisable to reorganize any banking institution as set out in section 528.90 , he shall, with the approval of the executive council, have power so to do on such terms and conditions as he may prescribe, including the right to issue stock upon such conditions as he, with the approval of the executive council, may prescribe, for such stock, and which shall be nonassessable.

528.94-Voluntary agreement-percentage governing. Nothing in this act shall prevent the voluntary adoption of any form of depositors agreement not now or heretofore in contravention of 
the statutes thereto provided and under any such agreement the percentages as provided in section 528.35 , shall be fully applicable.

528.95-Power to enter into. During the period of management by the superintendent of banking of any state bank, savings bank or trust company or private bank pursuant to sections 528.90 to 528.94, inclusive, any county, city, town, township, or school district, by its governing board at the board's discretion, may enter into depositors agreements looking toward the reorganization, reopening or consolidation of the bank to the extent of its unsecured and unpreferred claims.

The state may so agree through the executive council as to its unsecured and unpreferred claims.

The board of supervisors may at its discretion, enter into such depositor's agreements as to taxes for the state, school, townships, cities, towns, motor vehicle funds, primary road fund, or other purposes and for other funds created by law, whether regular, temporary, or special, which have been duly collected by the treasurer of the county and duly and regularly deposited by the county treasurer in a state bank, savings bank, trust company or private bank or any national bank whose deposit liability has been assumed by a state bank, savings bank or trust company or private bank prior to the period of management by the state superintendent of banking.

Any public body hereinbefore named may with depositors of any national bank enter into a depositors agreement with said bank, provided the form of said agreement shall be one that shall have been first approved by the superintendent of banking and by the executive council. Any depositor's agreement that has heretofore been entered into by any public body above referred to with any state, savings, national, or private bank or trust company in Iowa and to which depositors agreement no objections have been taken by court action, is hereby legalized and approved.

528.96-Depositors agreement-effect. Joining in such agreement shall not be a waiver of any preference or of the right to participate in state sinking fund for public deposits, but after receipt of payment from such fund or assignment of deposit to the treasurer of state, he shall represent the same and may, with approval of the executive council, join in such agreements.

528.97-Liability of treasurer. If the treasurer has duly and regularly deposited money in such bank, then after the reorganization; reopening, or consolidation of said bank he shall only be held to account for such amount of the deposit as remains on 
deposit in such bank after the reorganization, reopening or consolidation, irrespective of whether a depositor's agreement was entered into or not.

528.99.-Conditions precedent to reorganization. Before any savings bank, state bank, private bank, or trust company shall attempt to reorganize or take waivers or depositor's agreements from its depositors, the banking department shall make an examination of said bank and shall determine, with the approval of the governor, what can and should be required to be paid by the officers, directors, and stockholders of said bank or trust company and no waivers or depositor's agreements shall be taken until the amount so required shall have been paid in full in cash or in other securities to be approved by the governor and the superintendent of banking to the bank or trust company. Any stockholder, or assignee of such holders, upon paying an amount equal to the sum so required, may present his certificate or certificates of stock to the superintendent of banking, who shall endorse thereon the amount so paid, and thereupon the holder of such stock, or those claiming by, through or under such holder by sale, transfer, assignment or otherwise, shall thereafter be released from any further liability, statutory or otherwise, on such stock or any reissue thereof, to the extent of the amount so paid and endorsed thereon. Provided, however, that the banking department shall, with the approval of the governor, have the right to waive or modify any of the provisions or requirements of this act where a bank is not to resume or continue banking operations, and where waivers or depositor's agreements are taken as a part of a plan for reorganizing and/or liquidating such bank.

528.100-Applicability to prior waivers. Banks or trust companies now operating on waivers or depositors agreements heretofore taken shall be subject to and come within the provisions of this act. Except that no unexpired waivers or depositors agreements between such banks or trust companies and their depositors shall be abrogated hereby.

528.101-Segregation of assets-trust certificates. Before waivers or depositors agreements are taken as herein provided, the superintendent of banking may authorize the bank to set aside a percentage of its assets to be determined by him and which may be regarded as slow or doubtful and to segregate the same. The superintendent of banking shall determine, with the approval of the governor, the percentage of deposits which may be waived, and shall authorize the issuance of trust certificates by said bank in an amount equal to the deposits so waived and the delivery of such trust certificates to depositors in said bank whose de- 
posits exceed ten dollars, in an amount equal to the amount of deposits so waived by each such depositor. A dividend shall be declared at the end of each year covering the entire net earnings of the bank and the earnings of and collection from the segregated assets, which dividend shall be applied pro rata to the payment of outstanding certificates of trust as herein provided, no dividends on any common stock in such bank shall be paid as long as any trust certificates are outstanding, unless otherwise agreed upon between such bank or trust company and a majority of the depositors holding direct, unsecured and unpreferred obligations of such bank in excess of ten dollars each, and totaling in the aggregate amount seventy-five per cent of the direct, unsecured and unpreferred obligations, and approved by the superintendent of banking. Such certificates shall be preferred in earnings and have preference in liquidation only over the common stock of said bank.

528.102-Priority of certificates. All trust certificates issued under the provisions of this act shall have preference and priority on all of the assets of the bank ahead of the rights of the holders of the common stock, and shall be paid in full before the common stockholders shall be entitled to any dividends or profits, unless otherwise agreed upon between such bank or trust company and a majority of the depositors holding direct, unsecured and unpreferred obligations of such bank in excess of ten dollars each, and totaling in the aggregate amount seventy-five per cent of the direct, unsecured and unpreferred obligations, and approved by the superintendent of banking.

528.103-Priority under distribution of assets. Where trust certificates are issued pursuant to section 528.101, the holders of such certificates in event of the distribution of assets of the bank, shall have a claim ahead of common stockholders or depositors against any assets of said bank which have been segregated for the protection of such trust certificates.

528.104-Certificates non-taxable. The trust certificates issued under the provisions of this act shall be nonassessable and nontaxable.

528.105-Acceptance of certificates. Any county, city, town, township, or school district by its governing board, at the board's discretion, may accept the trust certificates authorized in this act for their deposits in any bank issuing the same. The state may so agree through the executive council to accept the trust certificates provided for in this act. Any county, city, town, township, or school district which was regularly a depositor in any national bank in Iowa the deposit liabilities of which have 
been assumed by any savings, state, national or private bank, or trust company, shall be held to be or to have been a depositor in such state incorporated bank or trust company or national bank or private bank.

528.106-Effect of acceptance. The acceptance of such trust certificates by public bodies shall not be a waiver of their right to participate in the state sinking fund for public deposits. In event of receivership or bankruptcy, the unpaid balance of any trust certificate held by any such public body shall be construed as a depositor's claim of such public body in accordance with the provisions of chapter 454 .

528.107-Liability of treasurer. If the treasurer of any public body has duly and regularly deposited money in such bank, then after the reorganization, reopening, or consolidation of said bank, he shall only be held to account for such amount of the deposit as remains on deposit in such bank after reorganization, reopening, or consolidation, irrespective of whether such trust certificates as provided herein, have been accepted by the public body or not.

528.108-Majority agreement governs minority. If a majority of the depositors, holding direct, unsecured, and unpreferred obligations of such bank in excess of ten dollars each, and totaling in the aggregate amount seventy-five per cent of the direct, unsecured, and unpreferred obligations, shall agree to come within the provisions of this act by accepting trust certificates as herein provided, then, and in that event, all of the depositors of such bank are bound thereby.

528.109-Retirement of certificates. Banks coming within the provisions of this act shall retire the trust certificates issued hereunder pro rata through the earnings of and the collections from the segregated assets and the net earnings of said bank as hereinbefore provided or agreed upon under the provisions of this act.

528.111-Certificate holders-number governing. In the event any state bank, savings bank or trust company organized under the laws of this state, proposing to issue preferred stock pursuant to the laws of this state, shall have theretofore been reorganized and/or recapitalized or shall then be in process of reorganization and/or recapitalization (whether pursuant to the provisions of sections 528.99 to 528.110 , inclusive, and amendments thereto, or otherwise) pursuant to a plan of reorganization and/or recapitalization providing that the future earnings or income of such state bank, savings bank or trust company, or any portion thereof be pledged, assigned, or trusteed for the benefit of depositors, creditors, or holders of trust certificates of such state bank, savings bank, or trust company (hereinafter, for convenience, referred to as 
"certificate holders"), the rights of such "certificate holders" in such earnings or income may, with the written consent of a majority of such "certificate holders" holding claims totaling in the aggregate seventy-five per cent of the claims of all "certificate holders" for whose benefit such earnings shall have been pledged, assigned, or trusteed, be made subordinate, junior, and inferior to the rights of holders of preferred stock issued pursuant to the laws of this state, both as to the payment of dividends and any sinking fund or other requirements, if any, for the retirement of such preferred stock.

Upon such written consent being executed by a majority in number of such "certificate holders" holding claims totaling in the aggregate seventy-five per cent of the claims of such "certificate holders", all such "certificate holders" shall be bound thereby whether or not they shall have consented.

528.112-Preferred stock issue. Such state banks, savings banks, or trust companies shall issue preferred stock of one or more classes in the same manner as provided by law for the issuance of preferred stock in state banks, savings banks, or trust companies organized under the laws of this state.

528.113-Public bodies-sinking fund. The state, through the executive council, in its discretion, and any county, city, town, municipality, township, or school district, in the discretion of its governing board, when a "certificate holder" as defined in section 528.111, may enter into the written consent and subordination agreement as provided in said section, through and by any member or officer designated for that purpose by such public body. Joining in such written consent and subordination agreement shall not be a waiver of any preference or of the right to participate in the state sinking fund for public deposits.

528.115-Waiver by certificate holders. In the event, any state bank, savings bank, or trust company, organized under the laws of this state, shall have heretofore reorganized and/or recapitalized, or shall be in the process of reorganization and/or recapitalization (whether pursuant to provisions of sections 528.99 to 528.110 , inclusive, and amendments thereto, or otherwise), pursuant to the plan of reorganization and/or recapitalization; providing, that the future earnings or income of such state bank, savings bank, or trust company, or any portion thereof, be pledged, assigned, or trusteed for the benefit of depositors, creditors, or holders of trust certificates of such state banks, savings banks, or trust companies (hereinafter for convenience referred to as "certificate holders"), the rights of such "certificate holders" in such earnings or income, or the application of the same or any 
part thereof to payment of trust certificates may, with written consent of the majority of such "certificate holders" holding claims totaling, in the aggregate, seventy-five per cent of the claims of all "certificate holders" for whose benefit such earnings have been pledged, assigned, or trusteed, be waived and the trust agreement and any other agreements pertaining thereto may be so modified to such extent; and the future earnings and income dealt with in any manner approved by the superintendent of banking.

Upon such written consent being executed by a majority in number of such "certificate holders" holding claims totaling, in the aggregate, seventy-five per cent of the claims of such "certificate holders", all such "certificate holders" shall be bound thereby, whether or not they shall have consented.

528.116-Waiver by public bodies. The state, through the executive council, in its discretion, and any county, city, town, municipality, township, or school district, in the discretion of its governing board, when a "certificate holder", as defined in section 528.115, may enter into the written consent and waiver agreement as provided in said section, through and by any member or officer designated for that purpose by such public body. Joining in such consent and waiver agreement shall not be a waiver of any preference or of the right to participate in the state sinking fund for public deposits.

528.117-Governing provisions. Insofar as the provisions of this act may conflict with any other act or parts thereof, the provisions of this act shall control.

528.118-Trusts-segregated assets-liquidations. Wherever a state bank, savings bank, or trust company has reorganized pursuant to law and the plan of reorganization provides for the creation of a trust fund made up of segregated assets of such bank or trust company against which trust certificates have issued and trustees have been appointed or designated to administer the fund and trust, and the liquidation of the trust assets has reached a point in the judgment of the trustees where the trust should be wound up and the trustees released and discharged and they shall become satisfied that the interests of certificate holders or creditors require the termination of the trust and its liquidation, the superintendent of banking may appoint an examiner in charge or a trustee or trustees of said trust with or without pay but if with pay then not in excess of that fixed by statute for examiners in charge, to assist him in the liquidation and distribution of the assets of the fund, whereupon the right of levy or execution or attachment, if any, against such trust fund or its assets shall be suspended. 
528.119-Accounting-discharge. In such event, the duties of the trustees as trustees shall be terminated and they shall be released and discharged of any further duties pertaining thereto upon making proper accounting to the superintendent of banking upon such notice as he or the court shall direct, as the case may be.

\section{PeRIod of Liquidation About Ended}

Under the foregoing provisions the twenty-five year period of liquidation of Iowa banks began in 1923 under prior legislative enactment is about concluded. It would be difficult to accurately estimate what the new law of 1933 has meant in dollars and cents to the depositors and stockholders in bank reorganization work. Moreover, it established a principle to be utilized in the future in Iowa, and in bank rehabilitation that has been followed by legislatures in other states, and quite definitely sowed the seed for the enactment of a law with like principle by the congress of the United States, approved by the president on March 3, 1933. It is significant that prior to that time the reorganization work carried on by the committee on Banking and Agricultural Credit Facilities of the Iowa Bankers Association apparently received only half-hearted response and scant co-operation from those in charge of Federal bank administration.

The orderly management of distressed banks under the direction of the Iowa banking department promised more happy and satisfactory conditions, and this was quickly realized, though the process has been so very orderly that a long time has been necessary to liquidate many of the institutions holding frozen assets. Activity in securing depositor's agreements with stockholders took on renewed impetus. Individuals and small groups held meetings attended by stockholders and bank depositors at which the provisions and advantages of the application of the law were outlined and explained. This was largely because discretionary power to invoke the legal proceedings had been vested in the officers and directors of the banks and could not originate or lie with the state banking department, to which application must be made for any assistance desired. 
The Iowa Bankers Association under the leadership of its officers and committeemen, having pressed the needfulness of securing depositor's agreements all during the period pending the time when the Iowa legislature might convene, had developed a wide organization in putting this plan into effect immediately. An illustration of the work done in almost numberless communities may be that aggressively pursued in Carroll, Breda, Auburn, Sac City and others in that section, which was largely the same as in other localities. Claude R. Cook, now residing in Des Moines, and serving as curator of the Iowa State Department of History and Archives, like a hundred or more other men, was one of the speakers at the meetings held in these places by those interested in "saving" banking institutions from the ruinous practice of a "run" and consequent receivership, without co-operation of its depositors. At these meetings in the course of his address he said in part:

\section{A Typical Appeal to Depositors}

You have been called here as depositors of money in this bank, and the statement about to be made to you will be as brief as is consistent with clarity. This meeting is held to explain the operation of the agreement plan and was called by the business men's committee. And when the term "business men" is used I mean farmers as well as those engaged in other lines of business, for no one is more a business man than the person we know as the farmer, who is the real nerve center of our whole community. So the term "business men" is used for convenience and brevity, but is all inclusive.

The issuance by Governor Herring, of Iowa, of a moratorium on all farm and chattel mortgages, so completely paralyzed the collection processes of banks, that there was nothing the banks could do but to take advantage of the "bank stabilization" law. This is known as Senate File No. 111. It is a law intended to make banks run proof and to avoid bank receiverships. Before its passage there was no legal way by which a bank in distress could avoid going into the hands of a receiver. The only thing that could be done was for the city or town mayor to declare a business holiday, with all its devastating results. The voluntary depositor's agreements were secured and if in sufficient proportion and number, and approved by the state banking department, the banks were opened and business generally resumed. But 
during the holiday period all business was at a standstill. It was not exactly illegal, but it was extra-legal.

It was to meet just such a situation that the "bank stabilization" law was passed. It is the answer to a long felt need in our state. Other states are now adopting it. In many respects the new national law is similar in its operation.

\section{Financial Distress World Wide}

If the depression had been confined to Iowa, or even to the United States, recovery would be much more simple. But the "World War" left the world in a bad way. We can take some comfort out of the fact, not that others are in misery, but that we are not the only ones who are not able to approximate and appraise properly coming events, nor were we alone in not being able to make things go. So, today we do not face a situation that is merely local. We face only a local phase of a world-wide condition. It is a part of the world of today and we have no choice as to whether we will face it. And the "bank stabilization" law is the best offering to date under which we may meet our part of the emergency.

Your bank is in distress because it is a part of the economic structure of the world. Conditions in other communities have communicated themselves to yours and the inevitable has taken place. It was to conserve the liquid as well as the other good assets of banks that the law was passed. In other words it was provided to prevent bank runs, the most deadly enemy of banking institutions, in fear and dread of which bankers are in almost constant danger. And it is exactly for that reason that your bank here has come under its operation. It is to save to this community the valuable assets and stability of the institution by early action before the depletion of its assets, thereby protecting the borrowers as well as the depositors.

In order to accomplish this and the benefits of the law become operative it is now necessary that $51 \%$ of the depositors above ten dollars controlling $75 \%$ of the money in the bank to sign "depositor's agreements" in which it is agreed to leave in the bank for a period not to exceed two years the amount on deposit at the time the bank came within the provisions of the new law. Amounts deposited since that date are segregated and not affected. Sixty percent of the amount on deposit in that manner will draw interest at the rate of two percent and can be paid out to the depositor at the option of the bank. The bank is authorized to transfer $40 \%$ of the deposits to the trustees. The bank will also assign to the trustees $40 \%$ of its assets, without recourse, in return for the $40 \%$ of depositor's money to be administered by the trustees solely for the benefit of depositors. 
The "depositor's agreement" form is drawn and approved by the State Superintendent of Banking. No bank or depositor's committee, nor anyone, can change any part of it without approval of the banking department. It is the only form in use and is being used everywhere in Iowa. When they have been signed they have to be approved by the State Superintendent of Banking, under whose supervision is the whole procedure. This depositor's meeting is not required under the law nor business men's teams authorized; however, as an aid to community and public spirit it was felt that it would be much better to have the whole matter presented to all of the depositors in this meeting and have everything completely and thoroughly understood.

The speaker then explained in detail who were affected, including trust funds and estates, all to be handled on the same basis, off-sets allowable, compensation of trustees, and the meeting thrown open to questions from depositors, the committeemen responding to queries. Mr. Cook then concluded his remarks, saying:

When these agreements are executed and approved you will have a run-proof bank and a place where depositors may safely leave their money. When $51 \%$ of the individual depositors representing $75 \%$ of the money deposits are signed, the plan is binding upon the other $49 \%$ of the individuals and the remaining $25 \%$ of money deposits. However, the hope is to make it unanimous and not to stop with only the required number and amount.

Will not everyone here show their faith, loyalty and devotion to their home town and community and go to their respective committees and sign the agreements. And then you will have a banking institution that is sound, confidence will be restored and you will be proud that you had a part in it.

This is your community and your home. The biggest and best thing you can do for it is not too good. The largest opportunity to be of service to your community is before you this morning. You are not working for the bank. You are working for yourselves. The bank is just as much a part of you as it is of the bank officers and stockholders. You can save your community now or you can lose it now. Through the Grace of God and the inherent, indomitable will of men and women you will save it!

\section{Secured Continuity of BANKIng Structure}

Similar meetings were held just as strong appeals were made in hundreds of Iowa communities and the response was uniformly favorable. At the discretion of the Superintendent of Banking the local management of the 
bank was either continued by its then officers by a part of them, or by any suitable person or persons he might select to continue the management. As soon as there developed a possibility of the bank surviving and succeeding as a going institution the details of its return to its stockholders was arranged at the earliest prac-ticable moment. Thus was preserved the continuity of the banking structure itself and a rehabilitating of the bank, giving it a fresh and new start in its existence, a procedure in line with the whole program of reconstruction which was going on at the time in nearly every line of business. It quickly worked for the upbuilding of the general morale of depositors and borrowers and stockholders and for bringing more general peace of mind so much needed in every community where previously distress, fear and financial upheaval had reigned. The banking business in these local communities was continued without further interruption while the necessary liquidation of the former assets was going on, the institutions being restored through an orderly process to a sound and constructive basis bringing a new day to the economic and financial situation in Iowa. And the law stands as a monument to the courage and sound judgment of those responsible for its coming into being, or assisted in the bringing to Iowa a new day in bank management. No longer are communities to be bereft in wholesale fashion of their banks and left without banking facilities, stunned by the paralysis that bank closings create and under the effects of such economic shocks and financial inconveniences left alone to build from the ashes of such community destruction a new community life. The provisions and processes of the law are still available for any similar incipient situation that might at some future time threaten any community. The state chartered banks are today in better condition perhaps than at any period of its history, none having closed in Iowa since 1939. 
Copyright of Annals of Iowa is the property of State of Iowa, by \& through the State Historical Society of Iowa and its content may not be copied or emailed to multiple sites or posted to a listserv without the copyright holder's express written permission. However, users may print, download, or email articles for individual use. 